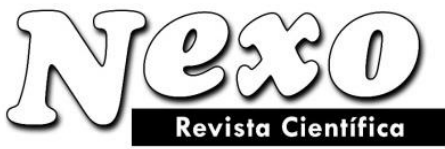

ISSN-E 1995-9516

Universidad Nacional de Ingeniería COPYRIGHT @ (UNI). TODOS LOS DERECHOS RESERVADOS

http://revistas.uni.edu.ni/index.php/Nexo

https://doi.org/10.5377/nexo.v34i06.13194

\title{
Application of fuzzy mathematics for choosing maintenance intervals for non- public railway tracks
}

\section{Aplicación de matemáticas difusas para elegir intervalos de mantenimiento para vías férreas no públicas}

\author{
Anna V. Ermakova \\ Samara State Transport University. Samara, Russia. \\ Corresponding author E-mail: ermakovanyut@mail.ru
}

(recibido/received: 28-octubre-2021; aceptado/accepted: 12-diciembre-2021)

\begin{abstract}
This article discusses the application of fuzzy mathematics for choosing time windows for the maintenance of non-public railway tracks. The design features of several stations and the points of junction of non-public railway tracks lead to hostile routes in the leads of the station. Moving the switching fleet through the neck creates hostility to the train route. To determine the optimal maintenance interval of non-public railway tracks, aimed at excluding hostility, it is necessary to know the throughput reserve of the railroad neck element in a certain time window. To localize the throughput reserve, it is proposed to divide the day into 30-minute intervals. This division will allow determining more accurately both the throughput reserve of the railroad neck element and the periods for servicing non-public railway tracks. The most appropriate way to calculate the throughput reserve is to use fuzzy numbers since this method allows taking into account the unequal capabilities of values within the intervals. Using the defuzzification procedure, a natural number is assigned to a given fuzzy number. After carrying out the defuzzification of the throughput reserve, the obtained values can be used to build an algorithm for selecting service intervals for non-public railway tracks.
\end{abstract}

Keywords: Fuzzy numbers; Reserve; Throughput; Rail railroad neck; Railroads shunting; Supply.

\section{RESUMEN}

Este artículo analiza la aplicación de las matemáticas difusas para elegir ventanas de tiempo para el mantenimiento de vías férreas no públicas. Las características de diseño de varias estaciones y los puntos de unión de vías férreas no públicas conducen a rutas hostiles en los conductos de la estación. Mover la flota de cambio a través del cuello crea hostilidad hacia la ruta del tren. Para determinar el intervalo de mantenimiento óptimo de vías férreas no públicas, con el objetivo de excluir la hostilidad, es necesario conocer la reserva de rendimiento del elemento del cuello del ferrocarril en una determinada ventana de tiempo. Para localizar la reserva de rendimiento, se propone dividir el día en intervalos de 30 minutos. Esta división permitirá determinar con mayor precisión tanto la reserva de rendimiento del elemento del cuello del ferrocarril como los períodos de servicio de las vías férreas no públicas. La forma más adecuada de calcular la reserva de rendimiento es utilizar números difusos, ya que este método permite tener en cuenta 
las capacidades desiguales de los valores dentro de los intervalos. Usando el procedimiento de defuzzificación, se asigna un número natural a un número difuso dado. Después de realizar la defuzzificación de la reserva de caudal, los valores obtenidos se pueden utilizar para construir un algoritmo para seleccionar intervalos de servicio para vías férreas no públicas.

Palabras claves: Números borrosos; Reserva; Rendimiento; Cuello de ferrocarril; Desvío de ferrocarriles; Suministro.

\section{INTRODUCTION}

The throughput reserve of the railroad neck element is characterized by the capability of the lead of the station to pass an additional number of trains, taking into account restrictions on its technical, technological, and structural features. To calculate the throughput reserve of the railroad neck element, it is necessary to know the time reserve $\left(T_{R}\right)$ and the average time needed for technological operations with one train $\left(\mathrm{T}_{\mathrm{av}}\right)$.

The values of $T_{R}$ and $T_{a v}$ cannot be determined precisely, since the actual time of passage of the railroad neck element by the train differs from the standard one. The type of incoming train can also vary, and consequently, the time needed for technological operations.

The application of the queuing theory can lead to incorrect results since the application of the probabilistic approach requires the so-called statistical stability, i.e. the

Alternatively, interval values for $T_{R}=\left[T_{R}^{\min }, T_{R}^{\max }\right]$ can be used. However, using the interval approach does not allow taking into account the unequal possibility of values within the concerned interval.

The article (Baumann et al., 2017) considers the application of Monte-Carlo simulation in the indicator approach to the assessment of freight transport scenarios. The article (Pokrovskaya and Fedorenko, 2020) describes a method for a comprehensive assessment of the parameters of terminal and logistics complexes based on the total rating.

In the research (Lamekhov and Chervotenko, 2020), the analysis of the methodology of the development stages based on the method of dynamic programming of transport infrastructure objects was carried out, and the possibility of applying this methodology to projects of multimodal transport and logistics centers was revealed.

The most optimal way to calculate the throughput reserve is to use fuzzy numbers which represent a generalization of interval numbers.

Fuzzy sets are used in (Trofimova, 2020) for planning, estimating the volume of cargo transportation according to a certain technological scheme based on the indicators of rolling stock by standard sizes, which should be taken into account when managing the resources and capacities of motor transport enterprises for the current period.

A fuzzy number is defined as a fuzzy set $R$ on the set of real numbers $\square$ with the membership function $\mu_{R}(x) \in[0,1]$, where $x \in \mathbb{R}$.

Extended binary arithmetic operations (addition, multiplication, etc.) for fuzzy numbers are defined via relevant operations for precise numbers using the generalization principle because using algebraic operations in such a way leads to a large number of computations. Fuzzy numbers should be presented in the $\boldsymbol{L} \boldsymbol{R}$-form (1). 


$$
\mu_{A}=\left\{\begin{array}{c}
L\left(\frac{x-a}{b-a}\right), x \in[a, b] \\
1, x \in[b, c] \\
R\left(\frac{x-d}{c-d}\right), x \in[c, d] \\
0, \text { otherwise }
\end{array}\right.
$$

Membership functions can be diverse depending on the $L$ and $R$ functions. The simplest ones are "triangular" numbers. In $L R$-form, a fuzzy number is written as a triple of numbers $A=\left\{m_{A}, \alpha_{A}, \beta_{A}\right\}$.

The theory of fuzzy sets, used in the article (Sun et al., 2019) allows assessing the impact of demand uncertainty on the problem of routing freights at the operational level in a powerful multimodal transport network consisting of schedule-based rail transportation and time-flexible road transportation.

\section{RESULTS}

To calculate the throughput reserve of the railroad neck element, it is necessary to know the busy time of each train passing through the element. Based on the above, the time occupied by passenger, freight, heavy and long trains for passing through the railroad neck element can be written as:

$>\quad \tilde{t}_{\text {neck }}^{\text {pass }}=\left\{t_{\text {neck }}^{\text {pass }}, \alpha_{\text {neck }}^{\text {pass }}, \beta_{\text {neck }}^{\text {pass }}\right\}$

The membership function of a passenger train $\mu_{\text {pass }}(\mathrm{t})$, passing through the railroad neck element is shown in Figure 1.

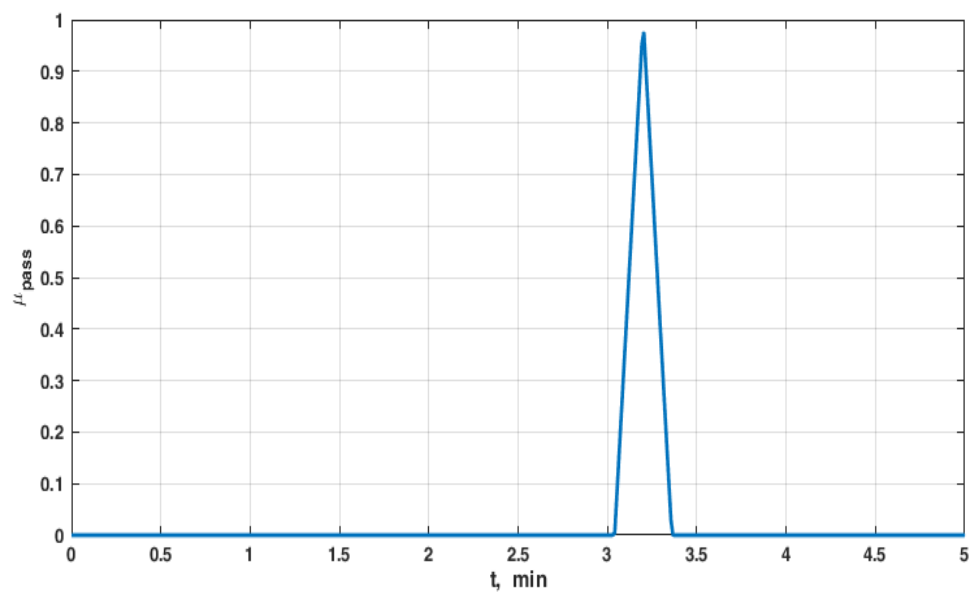

Figure 1. The membership function of a passenger train.

$>\quad \tilde{t}_{n e c k}^{f r}=\left\{t_{\text {neck }}^{f r}, \alpha_{\text {neck }}^{f r}, \beta_{\text {neck }}^{f r}\right\}$

The membership function of a freight train $\mu_{f r}(\mathrm{t})$, passing through the "neck" element is shown in Figure 2. 


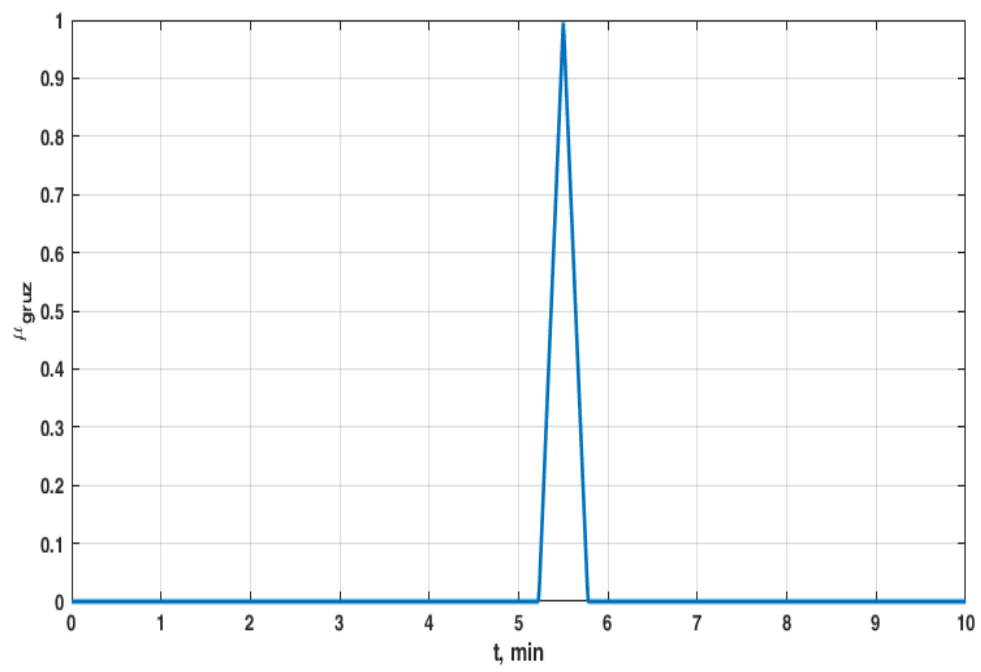

Figure 2. The membership function of a freight train.

$>\quad \tilde{t}_{\text {neck }}^{h v}=\left\{t_{\text {neck }}^{h v}, \alpha_{\text {neck }}^{h v}, \beta_{\text {neck }}^{h v}\right\}$

The membership function of a freight train $\mu_{f r}(\mathrm{t})$, passing through the railroad neck element is shown in Figure 3.

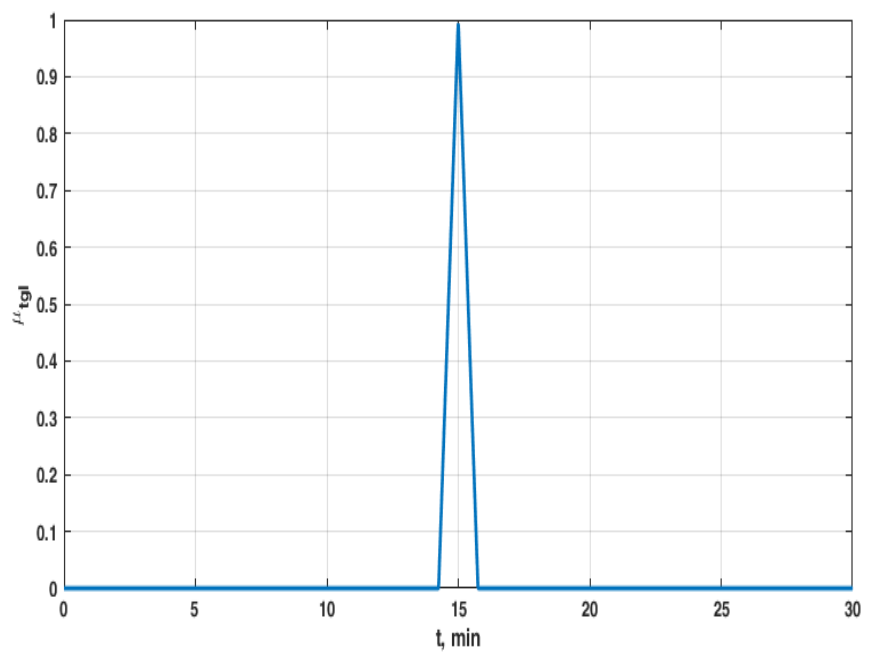

Figure 3. The membership function of a heavy train.

$>\quad \tilde{t}_{\text {neck }}^{l}=\left\{t_{\text {neck }}^{l}, \alpha_{\text {neck }}^{l}, \beta_{\text {neck }}^{l}\right\}$

The membership function of a long train $\mu_{l}(\mathrm{t})$, passing through the railroad neck element is shown in Figure 4. 


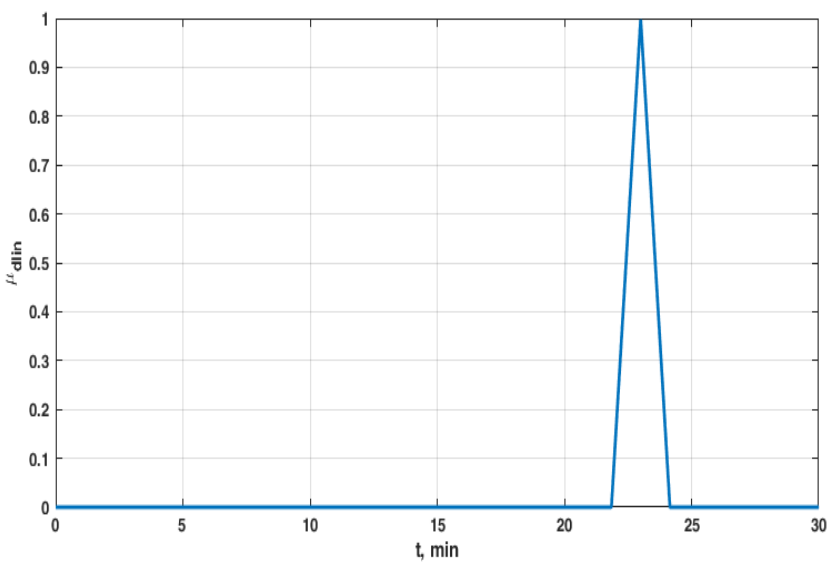

Figure 4. The membership function of a long train.

The estimate of the throughput reserve, obtained as a result of calculations is a fuzzy number. Using the defuzzification procedure, a natural number is assigned to this fuzzy number. The defuzzification of the fuzzy number $R_{n e c k}$ by the center of gravity method is carried out according to the formula (2):

$$
R_{n e c k}=\frac{\int_{\underline{x}}^{\bar{x}} x \mu_{R}(x) d x}{\int_{\underline{x}}^{\bar{x}} \mu_{R}(x) d x}
$$

After carrying out the defuzzification of the throughput reserve, the obtained values can be used to build an algorithm for selecting service intervals for non-public railway tracks. The proposed algorithm has several features:

1. To localize the throughput reserve, the day is divided into 30 minutes intervals. This division can be considered close to the optimal one for the following reasons: on the one hand, the interval for performing shunting maintenance of non-public railway tracks is specified, and on the other hand, it is impractical to make it even smaller, because:

- the interval will be less than the inter-interval time for the passage of double, heavy, and oversized trains.

- when trying to take small intervals, the probability of errors increases (due to the shift of the schedule).

2. To compare the time reserve on a 30-minute interval with the hourly interval reserves, let's move on to the relative throughput reserves $R_{r e l}$ (a unity means that the entire interval is free, while zero means that the interval is fully occupied).

3. The following algorithm is proposed to select time intervals for shunting maintenance of non-public railway tracks:

Step 1. Calculating relative reserves.

Step 2. Selecting the $n$ most free intervals (where $n$ is the number of supply/picking of railroad cars per day). Checking the condition $R_{\text {rel }}(i)>R o$ for these intervals. 
Figures 5 and 6 show the relative reserves for single-track and double-track necks, respectively.

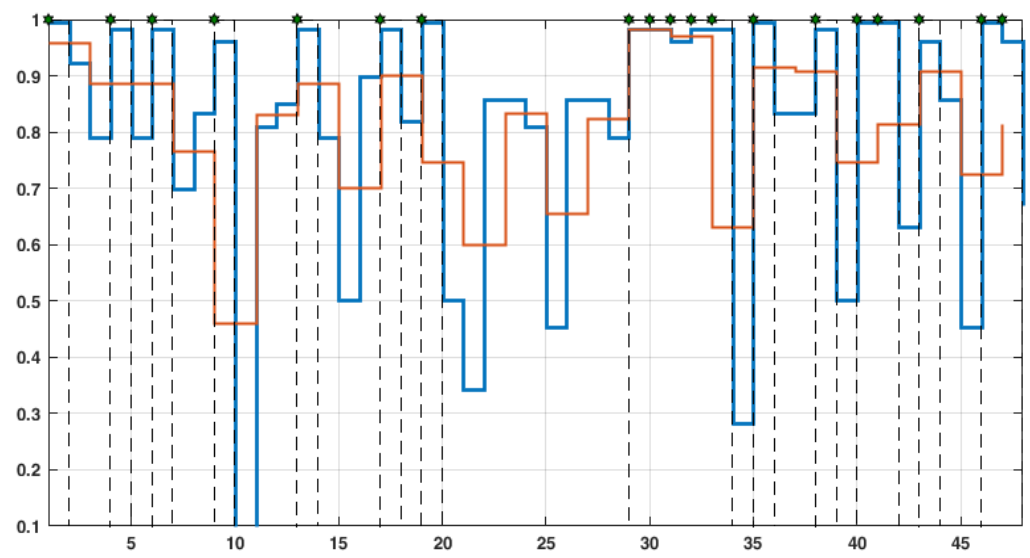

Figure 5. The relative reserve graph $R_{r e l}(i)$ of the single-track railroad neck of the station.

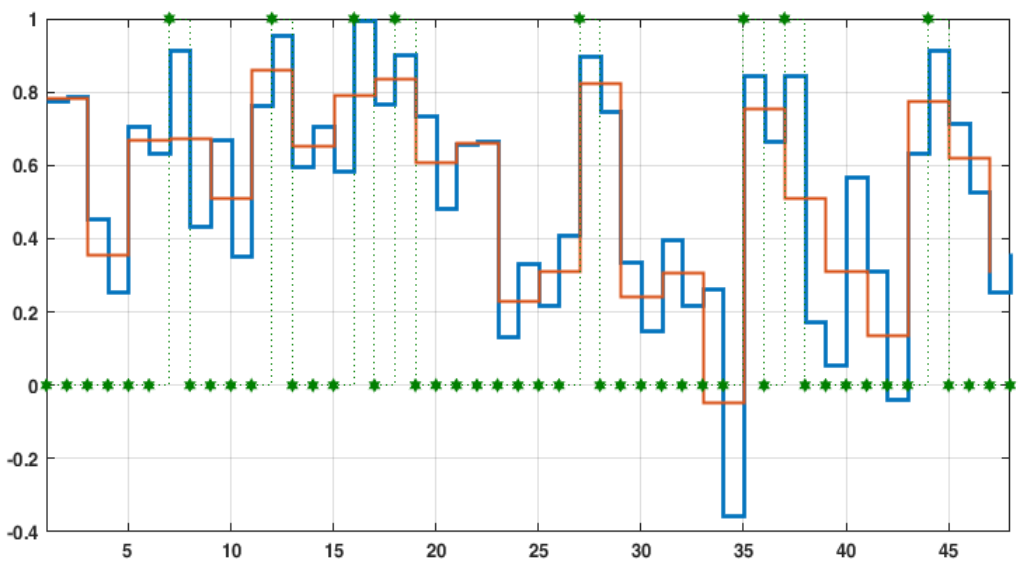

Figure 6. The relative reserve graph $R_{r e l}(i)$ of the double-track railroad neck of the station.

On the above graphs, the relative reserves of hourly periods are shown in red, half-hour ones are shown in blue lines. The asterisks at the top of the graph indicate the numbers of 30-minute intervals recommended for shunting maintenance of non-public railway tracks.

Shunting maintenance of non-public railway tracks at the recommended time intervals allows meeting the customer needs in transport services without reducing the throughput capacity of the station.

\section{CONCLUSIONS}

Based on the algorithm for selecting technologically efficient time windows for shunting maintenance of non-public tracks, the cargo owner will be able to determine the priority of the train approaching the station as well as supply/picking of railroad cars. A shift engineer of the traffic management directorate will be able to form an agreed schedule for the train approaching the station as well as supply/picking of railroad cars based on the data of the consignees and transfer this information to the dispatch of the transportation management center for execution. The developed schedule and railroad car traffic formation will allow 
gartering locomotives and locomotive crews, which will make it possible to rationally plan and organize local and train work at railroad stations and operating domains in general.

\section{REFERENCES}

Baumann, L., Behrendt, F. and Schmidtke, N. (2017). Applying Monte-Carlo simulation in an indicatorbased approach to evaluate freight transportation scenarios. In: Proceedings of the International Conference on Harbor Maritime and Multimodal Logistics M\&S, Barcelona, Spain, pp. 45-52.

Lamekhov, V. and Chervotenko, E. (2020). Usage of dynamic programming method in transport and logistics centers construction and development projects. In: Z. Popovic, A. Manakov and V. Breskich (Eds.), VIII International Scientific Siberian Transport Forum. TransSiberia 2019. Advances in intelligent systems and computing (Vol. 1115, pp. 357-366). Cham, Switzerland: Springer.

Pokrovskaya, O. and Fedorenko, R. (2020). Methods of rating assessment for terminal and logistics complexes. In: Z. Popovic, A. Manakov and V. Breskich (Eds.), VIII International Scientific Siberian Transport Forum. TransSiberia 2019. Advances in intelligent systems and computing (Vol. 1116, pp. 950959). Cham, Switzerland: Springer.

Sun, Y., Liang, X., Li, X. and Zhang, C. (2019). A fuzzy programming method for modeling demand uncertainty in the capacitated road-rail multimodal routing problem with time windows. Symmetry, 11 (1), 91-105.

Trofimova, L. (2020). Fuzzy set theory for planning the operation of a motor transport enterprise. In: Z. Popovic, A. Manakov and V. Breskich (Eds.), VIII International Scientific Siberian Transport Forum. TransSiberia 2019. Advances in intelligent systems and computing (Vol. 1116, pp. 617-626). Cham, Switzerland: Springer. 